\title{
Effect of Traditional supplementary snack on underweight children-A Systematic Review
}

\author{
Dr.Jyothi.H' ${ }^{\mathbf{1}}$, Dr.Mini Joseph ${ }^{2}$ \\ ${ }^{1,2}$ Assistant Professor in Food \& Nutrition, Department of Home science Government College for Women,
}

Trivandrum, Kerala, India.

\begin{abstract}
The period of pre-school children is an important stage for formation and preservation of health in the future. (Bergier et al., 2016). The aim of this research is to study the effect of a developed traditional supplementary snack on underweight pre-schoolers. The sample comprised of preschool children of 42-48 months, from the rural areas of Malappuram district, Kerala. Normal weight for age children formed the control group and underweight children constituted the experimental group. The anthropometric standards of the control group and experiment group showed statistical significance with respect to their height, weight, head circumference, chest circumference, and MUAC measurements. The average weight of children in control group lies in between the WHO reference median and -1SD value.The traditional supplementary snack was made from Barley, green gram, sesame seeds, jaggery and ghee. It provided an additional $1 / 3$ calories for the experimental group. Two balls $(100 \mathrm{gm})$ rich in macro and micronutrients (436.5 calories, $8.2 \mathrm{~g}$ protein, $171 \mathrm{mg}$ calcium, $119.5 \mathrm{mg}$ phosphorous and $2.55 \mathrm{mg}$ iron) were supplemented daily for a period 3months. The cost was Rs $4.25 / \mathrm{ball}(50 \mathrm{~g})$. The present study indicated that blending traditional supplementary food can improve the growth rate of underweight preschool children and help catch up and reach normal standards.
\end{abstract}

Keywords: Preschool children, supplementation, supplementary snack, weight for age, underweight, Barley, green gram, sesame.

\section{INTRODUCTION}

Nutritional status is the great mirror which shows the healthcare practices and its determinants of any country (Black et al., 2013). Worldwide it is estimated that every fourth child is affected by protein-energy malnutrition.

Supplementary food is any combination of ingredients which should be calorie dense, and can full fill and correct nutritional deficiencies in growing children. Effective supplementary food will meet additional one third calorie requirement for moderately malnourished children (Elizabeth et al., 2016). Targeted Supplementary Feeding Programmes (TSFPs) are the most commonly used approach for treating MAM (Annan et al., 2014). Targeted Supplementary Feeding Programmes use a variety of different products, including fortified blended flours and readyto-use supplementary food (RUSF) supplements (Lenters et al., 2013). The World Health Organization has issued guidance on the recommended nutrient composition of such supplements (WHO, 2012).Some studies have suggested that nutrition counseling, particularly focusing on improving infant and young child feeding practices, may be as effective as specialized food-based interventions for the treatment of MAM (Nikiema et al., 2014, Ashworth \& Ferguson, 2009).

Strategies for tackling childhood stunting and micronutrient deficiencies may include child-centred specific nutrition counseling, cash transfers, linkage to social protection services (safety net programme, income generation schemes), a food multimix approach using locally available food, and using specialised food supplements such as fortified blended flours or ready-to-use supplementary foods (Lenters et al., 2013., Nikiema et al., 2014., Ashworth \& Ferguson, 2009., Zotor \& Amuna, 2008).. The author suggests supplementary feeding for children who are breastfed for minimum for one year or more (Nsereko et al., 2018).

The present experiment was conducted to assess the impact of supplementary food on the nutritional status of low weight preschool children who were identified from the rural areas of Malappuram district. In this interventional experiment, a food supplementation strategy was administered to compensate for the weight of low weight for age children.

\section{METHODOLOGY}

This study assessed the effect of supplementation of the developed snack for preschool children of low weight for age ( $3 \frac{1}{2} 2$ - 4 years, ie $42-48$ months, $N=50$ ). Twenty-five children with normal weight for age were selected as control group and twenty-five children with low weight for age were selected as experiment group. The product developed was given as food supplement for a period of 3 months (90 days) for experiment group. Data pertaining to anthropometry 
Vol. 8, Issue 10, October 2021

DOI: 10.17148/IARJSET.2021.81012

were collected before and after intervention. The dietary profile collected before intervention using 24 hour recall for three days and the nutrients were computed. The supplemented snack contains 439 calories, $7.8 \mathrm{~g}$ protein, $96.5 \mathrm{mg}$ calcium, $133 \mathrm{mg}$ phosphorous and $2.41 \mathrm{mg}$ iron per $100 \mathrm{~g}$ of 'ladoo'. The cost was Rs 4.25 /ball, (50g).

\section{RESULTS AND DISCUSSION}

Table.1 Distribution of respondents on the basis of religion, caste $\&$ family size

\begin{tabular}{|c|c|c|c|c|c|c|c|c|}
\hline \multirow[b]{2}{*}{ Groups } & \multicolumn{3}{|c|}{ Religion } & \multicolumn{2}{|l|}{ Caste } & \multicolumn{3}{|c|}{ Family size } \\
\hline & 롶 & $\stackrel{\Xi}{\Xi}$ & 苞 & 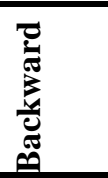 & 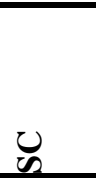 & n & 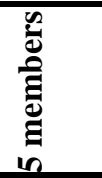 & 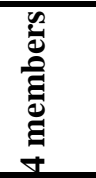 \\
\hline $\begin{array}{l}\text { Control } \\
\text { group }\end{array}$ & $\begin{array}{l}7 \\
(28 \%)\end{array}$ & $\begin{array}{l}18 \\
(72 \%)\end{array}$ & $\begin{array}{l}0 \\
( \\
0 \%) \\
\end{array}$ & $\begin{array}{l}24 \\
(96 \%)\end{array}$ & $\begin{array}{l}1 \\
(4 \%)\end{array}$ & $\begin{array}{l}18 \\
(72 \%)\end{array}$ & $\begin{array}{l}5 \\
(20 \%)\end{array}$ & $\begin{array}{l}2 \\
(8 \%)\end{array}$ \\
\hline $\begin{array}{l}\text { Expt. } \\
\text { Group }\end{array}$ & $\begin{array}{l}6 \\
(24 \%)\end{array}$ & $\begin{array}{l}19 \\
(76 \%)\end{array}$ & $\begin{array}{l}0 \\
( \\
0 \%)\end{array}$ & $\begin{array}{l}23 \\
(92 \%)\end{array}$ & $\begin{array}{l}2 \\
(8 \%)\end{array}$ & $\begin{array}{l}23 \\
(92 \%)\end{array}$ & $\begin{array}{l}2 \\
(8 \%)\end{array}$ & $\begin{array}{l}0 \\
(0 \%)\end{array}$ \\
\hline
\end{tabular}

Table. 1 shows, on basis of religion, 28 percent of the control and 24 percent in the experiment group belonged to Hindus, 72 percent and 76 percent from control and experiment groups respectively belongs to Muslims. 96 percent of the control group and 92 percent of experiment group were from the backward category. SC community in these groups was 4 percent and 8 percent respectively. Based on the size 72, 20, 8 percent of the family possesses more than five, five and four members respectively in the control group. In the case of experiment group, 92 percent of family had greater than five members, and 8 percent had 5 members in their family.

Table.2 Distribution of respondents on the basis of type of family, education \& occupation

\begin{tabular}{|l|l|l|l|l|l|l|l|}
\hline & \multicolumn{2}{|l|}{ Type of family } & \multicolumn{2}{|l|}{$\begin{array}{l}\text { Educational } \\
\text { status of parent } \\
\text { up to10 } \\
\text { class })\end{array}$} & \multicolumn{3}{l|}{ Occupation of parent } \\
\hline & Joint & Nuclear & Father & Mother & Coolie & Agriculture & Business \\
\hline $\begin{array}{l}\text { Control } \\
\text { group }\end{array}$ & $\begin{array}{l}17 \\
(68 \%)\end{array}$ & $8(32 \%)$ & $\begin{array}{l}23 \\
(92 \%)\end{array}$ & $18(2 \%)$ & $\begin{array}{l}23 \\
(92 \%)\end{array}$ & $0(0 \%)$ & $2(8 \%)$ \\
\hline $\begin{array}{l}\text { Experiment } \\
\text { group }\end{array}$ & $\begin{array}{l}23 \\
(92 \%)\end{array}$ & $2(8 \%)$ & $\begin{array}{l}25 \\
(100 \%)\end{array}$ & $\begin{array}{l}13 \\
(52 \%)\end{array}$ & $\begin{array}{l}19 \\
(76 \%)\end{array}$ & $1(4 \%)$ & $5(20 \%)$ \\
\hline
\end{tabular}

From Table.2, 68 percent of children from the control group and 92 percent from the experiment group belongs to joint family. 92 percent of father and 72 percent of mother in the control group had education up to $10^{\text {th }}$ class. In the experiment group, 52 percent of mother and cent percentage father obtained education up to $10^{\text {th }}$ class. Majority of the parents from both the groups are daily wagers (92\% and 76\%). Moreover 4 percent depend on agriculture as their livelihood.

Table. 3 Variance analysis for control and experiment groups

\begin{tabular}{|l|l|l|l|l|}
\hline \multicolumn{1}{|c|}{ Group } & $\begin{array}{l}\text { Average monthly } \\
\text { income (Rs.) }\end{array}$ & $\begin{array}{l}\text { Per capita income } \\
(\text { Rs.) }\end{array}$ & F-value & P-value \\
\hline Control group (N=25) & $22080 \pm 1869$ & $3723 \pm 622$ & 0.006 & 0.938 \\
\hline Experiment group (N=25) & $22120 \pm 1740$ & $3499 \pm 285$ & 2.682 & 0.108 \\
\hline
\end{tabular}


Vol. 8, Issue 10, October 2021

DOI: 10.17148/IARJSET.2021.81012

Table. 3 shows that there was no statistical difference in the monthly income and per capita income of the control group and experimental group. Thus these groups show no economic disparity between them. Both the groups were homogeneous with respect to economic variable.

Table.4 Anthropometric measurements of the groups

\begin{tabular}{|c|c|c|c|c|c|}
\hline Anthropometry & Groups & Mean & $\begin{array}{l}\text { Std. } \\
\text { Deviation }\end{array}$ & F-value & $P$ - value \\
\hline \multirow{2}{*}{ Height (cm) } & Control & 96.36 & 2.8705 & \multirow{2}{*}{4.571} & \multirow{2}{*}{0.038} \\
\hline & Experiment & 95.04 & 1.1358 & & \\
\hline \multirow{2}{*}{ Weight (kg) } & control & 14.612 & 0.6366 & \multirow{2}{*}{250.862} & \multirow{2}{*}{0.000} \\
\hline & Experiment & 11.628 & 0.6943 & & \\
\hline \multirow{2}{*}{ Head circumference $(\mathrm{cm})$} & control & 49 & 1.118 & \multirow{2}{*}{22.840} & \multirow{2}{*}{0.000} \\
\hline & Experiment & 47.72 & 0.7371 & & \\
\hline \multirow{2}{*}{ Chest circumference $(\mathrm{cm})$} & control & 48.4 & 1.5546 & \multirow{2}{*}{13.431} & \multirow{2}{*}{0.001} \\
\hline & Experiment & 47.08 & 0.9092 & & \\
\hline \multirow{2}{*}{ MUAC (cm) } & control & 14.44 & 0.3629 & \multirow{2}{*}{399.555} & \multirow{2}{*}{0.000} \\
\hline & Experiment & 12.492 & 0.3252 & & \\
\hline
\end{tabular}

Table.4 shows the mean anthropometric measurements of the control group and experimental group. It showed statistical significance between the groups with respect to their height, weight, head circumference, chest circumference, and MUAC measurements.

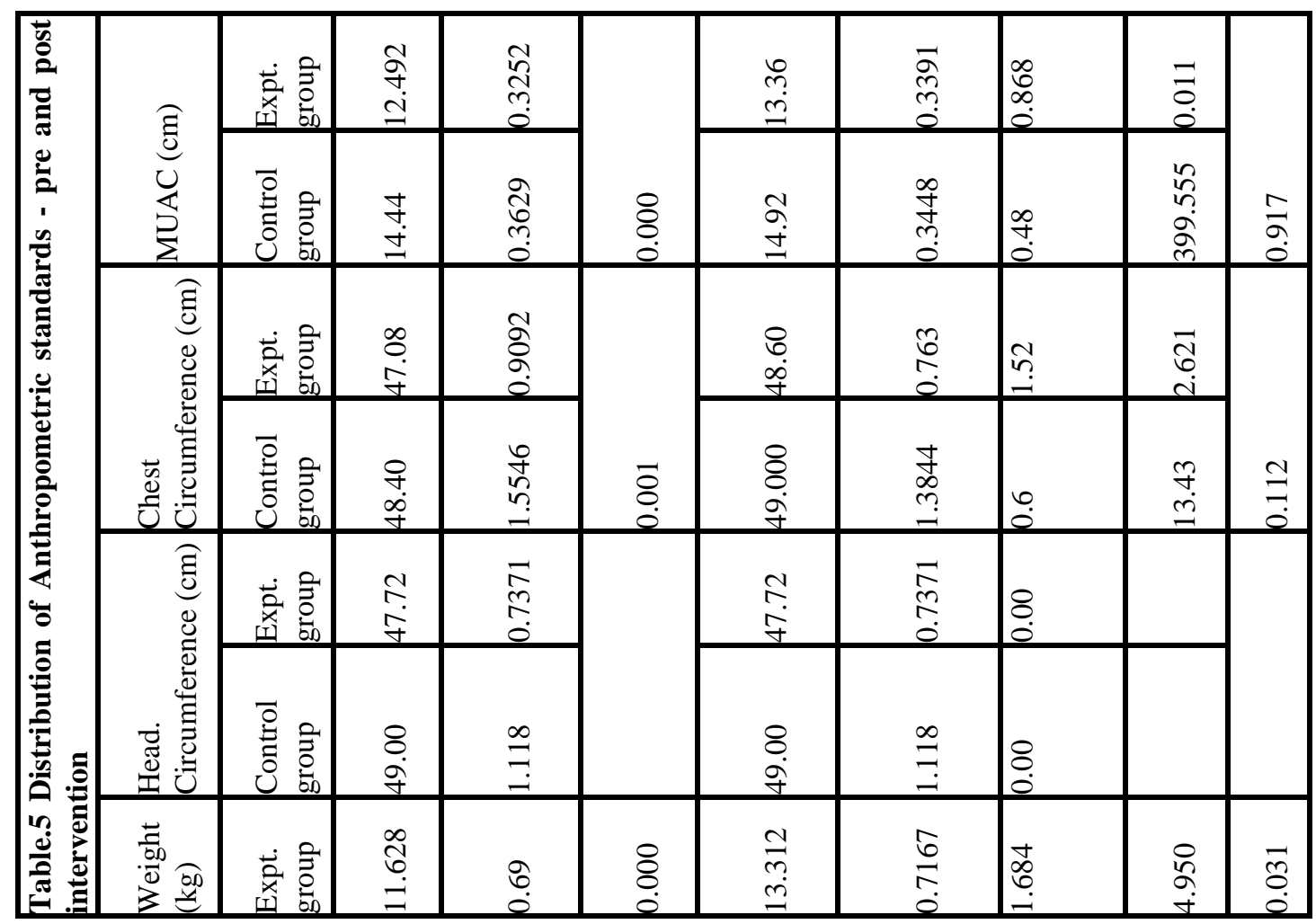


Vol. 8, Issue 10, October 2021

DOI: 10.17148/IARJSET.2021.81012

\begin{tabular}{|c|c|c|c|c|c|c|c|c|c|}
\hline & \begin{tabular}{ll}
$\overline{0}$ & \\
\multirow{\Xi}{0}{} & 0 \\
0 & 0 \\
$ن$ & 0 \\
\end{tabular} & $\begin{array}{l}\stackrel{1}{6} \\
\dot{\Xi} \\
\end{array}$ & \begin{tabular}{l}
$\stackrel{f}{8}$ \\
\multirow{0}{0}{} \\
$\dot{0}$
\end{tabular} & & $\begin{array}{l}8 \\
\stackrel{8}{10} \\
\end{array}$ & $\begin{array}{l}n \\
\frac{n}{n} \\
\vdots \\
0\end{array}$ & \begin{tabular}{l}
$\infty$ \\
\multirow{1}{*}{} \\
$n$ \\
0
\end{tabular} & $\begin{array}{l}0 \\
\infty \\
\dot{\circ} \\
\\
\end{array}$ & \\
\hline \multirow{2}{*}{ 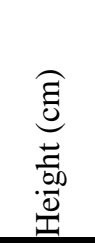 } & 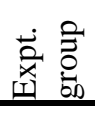 & 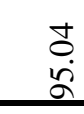 & $\begin{array}{l}\infty \\
\stackrel{n}{n} \\
\stackrel{?}{=}\end{array}$ & & 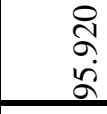 & $\stackrel{n}{\beth}$ & $\begin{array}{l}\infty \\
\infty \\
0 \\
0\end{array}$ & $\begin{array}{l}8 \\
0 \\
\end{array}$ & \\
\hline & 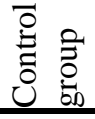 & $\begin{array}{l}0 \\
\text { n̊ } \\
\text { å }\end{array}$ & $\begin{array}{l}n \\
\infty \\
\infty \\
i \\
\end{array}$ & $\begin{array}{l}\infty \\
0 \\
0 \\
0\end{array}$ & $\begin{array}{l}\text { o } \\
\text { o. } \\
\text { á }\end{array}$ & 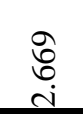 & \begin{tabular}{|l}
$\infty$ \\
0 \\
0
\end{tabular} & in & 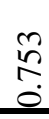 \\
\hline \multirow{2}{*}{ 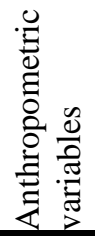 } & 苛 & 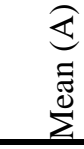 & 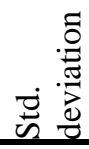 & $\begin{array}{l}\stackrel{0}{J} \\
\frac{\pi}{7} \\
\dot{2} \\
\end{array}$ & 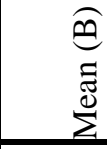 & 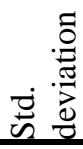 & 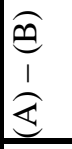 & 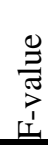 & \begin{tabular}{l}
0 \\
$\frac{0}{3}$ \\
\multirow{2}{*}{} \\
1 \\
\end{tabular} \\
\hline & & \multicolumn{3}{|c|}{ Pre intervention } & \multicolumn{2}{|c|}{ Post intervention } & Diff & & \\
\hline
\end{tabular}

Table.5, anthropometric measurements of the pre and post-intervention revealed that the intervention study was effective with an increased growth spurt in the experiment group. The p-values prior to intervention show that all the anthropometric measurements were significant in between the control and the experiment groups. After intervention, except for weight the p-value is greater than 0.05. It further implies that there was no statistical difference between these groups after intervention. In the case of weight the p-value changed from 0.000 to 0.031 . The control group had a weight increase of $0.548 \mathrm{~kg}$ after 3 months, while the experiment group had an increased growth rate of $1.684 \mathrm{~kg}$ after supplementation. The difference in mean weights of the control and experiment group before intervention was 2.984 (14.612-11.628), but after intervention it become 1.848 (15.16-13.312). About 38 percent of weight gain occurred in the experiment group over control group on an average. These values points out that weight difference of children in between the groups get reduced. Thus it shows the supplementation provided some extent of improvement in the weight of children. More evidences was brought for this by computing the $\mathrm{Z}$ scores of these groups.

Table.6 Z score summary - pre and post supplementation intervention

\begin{tabular}{|l|l|l|l|l|l|l|l|}
\hline \multicolumn{9}{|l|}{ Control group } & \multicolumn{3}{l|}{ Experiment group } \\
\hline Pre intervention & \multicolumn{2}{l|}{ Post intervention } & \multicolumn{2}{l|}{ Pre intervention } & \multicolumn{2}{l|}{ Post intervention } \\
\hline $\begin{array}{l}\text { Weight } \\
(\mathbf{k g})\end{array}$ & WAZ & $\begin{array}{l}\text { Weight } \\
(\mathbf{k g})\end{array}$ & WAZ & $\begin{array}{l}\text { Weight } \\
(\mathbf{k g})\end{array}$ & $\mathbf{W A Z}$ & $\begin{array}{l}\text { Weight } \\
(\mathbf{k g})\end{array}$ & WAZ \\
\hline 13.9 & -1.33 & 14.5 & -1.24 & 10.1 & -3.16 & 12 & -2.36 \\
\hline 13.8 & -1.39 & 14.5 & -1.24 & 12 & -2.39 & 13.9 & -1.57 \\
\hline 13.8 & -1.39 & 14.3 & -1.35 & 10.4 & -2.97 & 12.1 & -2.26 \\
\hline 13.7 & -1.19 & 14.4 & -1.05 & 11.9 & -2.21 & 13.8 & -1.44 \\
\hline 13.9 & -1.08 & 14.4 & -1.05 & 12.1 & -2.33 & 13.8 & -1.62 \\
\hline 14.7 & -0.65 & 15.3 & -0.58 & 11.9 & -1.89 & 13.4 & -1.28 \\
\hline 15.2 & -0.46 & 15.7 & -0.43 & 10 & -2.97 & 11.5 & -2.33 \\
\hline 13.7 & -1.14 & 14.4 & -1 & 12 & -2.29 & 13.7 & -1.51 \\
\hline 15.4 & 0.11 & 15.7 & 0 & 12 & -2.06 & 13.6 & -1.38 \\
\hline 14.5 & -0.4 & 15.1 & -0.33 & 12 & -2.24 & 13.8 & -1.39 \\
\hline 15.4 & -0.37 & 15.8 & -0.41 & 10.2 & -3.31 & 11.8 & -2.54 \\
\hline 15.5 & -0.32 & 15.9 & -0.36 & 12.1 & -2.18 & 13.6 & -1.5 \\
\hline 15.2 & -0.28 & 15.7 & -0.31 & 12.3 & -2.22 & 14 & -1.51 \\
\hline 15 & -0.58 & 15.4 & -0.62 & 12.3 & -2.11 & 14.1 & -1.3 \\
\hline 14.9 & -0.72 & 15.4 & -0.68 & 12.3 & -2.06 & 14 & -1.28 \\
\hline 14 & -0.94 & 14.6 & -0.87 & 12 & -2 & 13.6 & -1.32 \\
\hline 14.5 & -0.84 & 15.1 & -0.77 & 11.5 & -2.29 & 13.2 & -1.53 \\
\hline
\end{tabular}


International Advanced Research Journal in Science, Engineering and Technology

Vol. 8, Issue 10, October 2021

DOI: $10.17148 /$ IARJSET.2021.81012

\begin{tabular}{|l|l|l|l|l|l|l|l|}
\hline 14.2 & -1 & 14.8 & -0.92 & 11.4 & -2.39 & 12.8 & -1.79 \\
\hline 15.5 & -0.39 & 16 & -0.37 & 12 & -2.33 & 13.7 & -1.58 \\
\hline 13.9 & -1.33 & 14.5 & -1.24 & 12 & -2.29 & 13.6 & -1.57 \\
\hline 14.4 & -0.72 & 14.9 & -0.72 & 11.6 & -2.23 & 13.4 & -1.42 \\
\hline 15.3 & -0.56 & 15.9 & -0.49 & 11.7 & -2.27 & 13.4 & -1.58 \\
\hline 15 & -0.39 & 15.7 & -0.31 & 11.8 & -2.5 & 13.3 & -1.89 \\
\hline 14.9 & -0.17 & 15.4 & -0.17 & 11.6 & -2.61 & 13.4 & -1.84 \\
\hline 15 & -0.18 & 15.6 & -0.12 & 11.5 & -2.42 & 13.3 & -1.69 \\
\hline
\end{tabular}

Table. 6 gives the $\mathrm{z}$ scores for weight for age of the children in the control and the experiment group respectively in pre and post intervention. The $\mathrm{z}$ scores of all the twenty five children of the control group were greater than -2SD of the standard population. Hence, before and after intervention they fall in the normal range. However the $\mathrm{z}$ scores of the experiment group children were lesser than -2SD (92\%), before supplementation intervention so they lie in underweight category. But after supplementation, the $\mathrm{z}$ scores crosses above -2SD of the standard population (84\%). It shows that after intervention only 16 percent children were lying in underweight category. This further implies that the supplementation of developed product gave a strong positive impact on the nutritional status of these children.

The same conclusion was drawing from the statistical analysis explained with the Table.5 and 6. From the above two comparisons, it can be to concluded that proper supplementation with systematically developed supplementary foods for a continuous period of six months or more can enhance the nutritional status of children and thereby reduce the malnutrition.

\section{CONCLUSION}

The present study indicated that blending traditional supplementary food can improve the growth rate of underweight preschool children and help catch up and reach normal standards.

\section{REFERENCES}

1.Bergier, J., Bergier, B., \& Tsos, A. (2016). Variations in Physical Activity of Male and Female Students from Different countries. Iran J Public Health, 45(5):705-707.

2.Black, R. E.; Victora, C. G.; Walker, S. P., Bhutta, Z. A., Christian, P., de Onis, M., Ezzati, M., Grantham-McGregor, S., Katz, J., Martorell, R., \& Uauy, R. (2013) Maternal and Child Nutrition Study Group Maternal and Child Undernutrition and Overweight in Low-Income and MiddleIncome Countries. Lancet, 382 (9890), 427-451.

3.Elizabeth., Kristjansson., Damian Franci, Vivian Welch.(2016). Supplementary Feeding for Improving the Health of Disadvantaged Infants and Children What Works and Why? Systematic Review Summary 5 The International Initiative for Impact Evaluation 2.

4.Annan, R., Webb, P., \& Brown, R. (2014) Management of Moderate Acute Malnutrition (MAM): Current Knowledge and Practice. CMAM Forum TechnicalBrief; Available: http://www.cmamforum.org/Pool/Resources/ MAM-management-CMAM-Forum-Technical-Brief-Sept-2014-.pdf

5.Lenters, L. M., Wazny, K., Webb, P., Ahmed, T., \& Bhutta, Z. A. (2013) Treatment of severe and moderate acute malnutrition in low- and middleincome settings: a systematic review, meta-analysis and Delphi process. BMC Public Health. 13: S23 10.1186/ 1471-2458-13-S3-S23.

6.WHO. (2012) Technical note: supplementary foods for the management of moderate acute malnutrition in infants and children $6-59$ months of age WHO: Geneva;.

7.Nikiema, L., Huybregts, L., Kolsteren, P., Lanou, H., Tiendrebeogo, S., Bouckaert, K., Kouanda, S., Sondo, B., \& Roberfroid, D. (2014)Treating Moderate Acute Malnutrition in First-Line Health Services: An Effectiveness Cluster-Randomized Trial in Burkina Faso. Am J Clin Nutr 100 (1), 241-249.

8.Ashworth, A., \& Ferguson, E. (2009) Dietary counseling in the management of moderate malnourishment in children. Food Nutr Bull. 30, S 405433.

9.Zotor, F. B., \& Amuna, P. (2008) The food multimix concept: new innovative approach to meeting nutritional challenges in Sub-Saharan Africa. Proc Nutr Soc.67: 98-104. 10.1017/S0029665108006071.

10.Nsereko, E., Mukabutera, A., Iyakaremye, D., Umwungerimwiza, Y. D., Mbarushimana, V., \& Nzayirambaho, M. (2018). Early feeding practices and stunting in Rwandan children: a cross-sectional study from the 2010 Rwanda demographic and health survey. The Pan African medical journal, 29, 157. 